\title{
Islam, Buddhism, and the New Sciences
}

\author{
Eric Winkel
}

\section{Introduction}

While exploring convergences between Islam and contemporary science, I came across a recent book by the Dalai Lama ${ }^{1}$ which describes his interactions with Buddhism and science. In fact, the Dalai Lama is ideally suited to be a bridge between spirituality and science. His stature means that he does not merely read Thomas Merton, Carl Friedrich von Weizsäcker, Karl Popper, and David Bohm - he meets them. His seven decades means that he spans the most significant changes that technology and science have made on human society. And his understanding of Buddhism in a non-doctrinaire fashion means that he can see "spirituality and science [as] different but complementary investigative approaches with the same greater goal, of seeking the truth". ${ }^{2}$ Ideas from this book seemed to be foundational for my ongoing work on projective geometries and topologies in Islamic eschatology, and I look now at some of these ideas as a basis for identifying approaches and linkages from Buddhism, Islam, and contemporary science. I hope these approaches will constitute a fruitful addition to a conversation among Buddhists, Muslims, and the practitioners of the new sciences.

\section{Emptiness}

The split between science and religion has many consequences. Surely, one very important area is the perception of reality. For mainstream science, material reality is ultimate or at least the only arena open to rational discussion; for religions, this reality we experience is neither absolute nor final. For Buddhism, the Dalai Lama describes the theory of emptiness as the "deep recognition that there is a fundamental disparity between the way we perceive the world, including our own existence in it, and the way things actually are". ${ }^{3}$ In Islam, the role of prophets is to warn; meaning, to warn people that their perceptions of reality are wrong. Some people think that they need to kill an infant girl because she will decrease their material well-being; some people think that their deeds are not important because eventually they will die and exist no longer; some people think injustice is superior to justice, and superstition to belief in unity. Prophets tell them otherwise.

At the level of the physical world, the Dalai Lama says "we tend to relate to the world and to ourselves as if these entities possess self-enclosed, definable, discrete,

* Eric Winkel is Principal Research Fellow at IAIS Malaysia. 
and enduring reality". ${ }^{4}$ Scientists are not immune to the conceptualisation of a world of "bricks", as some describe it, even though their research shows a quite different reality.

Neuropsychological research, for example, works from the assumption that "brain mechanisms will ultimately suffice to explain all psychologically described phenomena". Such an assumption seems to stem "from the idea that the brain is made up entirely of material particles and fields". Terms such as feeling, knowing, and effort, then, are ignored. "This theoretical restriction is motivated primarily by ideas about the natural world that have been known to be fundamentally incorrect for more than three-quarters of a century." ${ }^{5}$

The famous quantum problem of the observer provides an example of paradox arising from trying to match reality with 'bricks' or a similar metaphor. The assumption is that there is a particle with momentum and position, and the act of observation disturbs the particle. In some interpretations, however, there is a question whether there really is a particle with momentum and position before being observed. To counter this extreme subjectivism, the physicist and theoretical biologist Erwin Schrödinger (d. 1961) came up with the thought experiment of the cat in the box with a decaying radioactive poison. According to contemporary quantum mechanical interpretation, he was saying, the cat is both alive and dead until the box is open and the state is observed. As such a situation was obviously impossible, there must be something wrong with the model.

We can propose a similar paradox to Schrödinger's cat. Take words that are their own antonyms. "The two cleaved." What does "cleaved" mean in that sentence? Well, it does not really mean anything until a context is supplied. Let us supply one context. "The lovers were cleaved in holy matrimony." Let us supply another. "With one blow he cleaved the rock." One means 'join together' and the other means 'split apart'. So our 'cat' paradox tells us the original sentence sits in a box and means one thing and its opposite at the same time, until someone looks at it - gives it a context - and interprets it. We can do the same with 'screen'. "What they screened was so offensive we should have screened it from innocent eyes." Meaning, then, belongs not to the 'brick' but to the circumstance. ${ }^{6}$

Philosophers of science contrast classical physics from quantum physics with the role of the observer. Classical Newtonian physics centres around an anonymous observer who looks out at a Cartesian grid, himself standing at the 0,0 point. Philosophers of science sensitive to gender point out the gendered elements of classical physics: the godly male whose gaze goes wherever he likes; the effort of science to understand so as to control, and especially, to control Mother Nature, the feminine; taking the physics of planetary motion and miniaturising that to neurons bouncing around in brains as the at least potentially complete picture of consciousness and reality; ${ }^{7}$ and so on. In contrast, quantum physics assumes that 
particle and observer are connected. Quantum physics may be interpreted as a science where connections, relationships, and unities are important.

\section{Conclusions and Recommendations}

The way we use words, such as 'Muslim' and 'Islam', reveals underlying assumptions. Probably it is owing to the British Raj that the sub-continent now seems to have clear distinctions in religion. A century ago, and still in many places, clear distinctions in religion were impossible. The Census Report of 1881, describing an encounter with some hill people, says,

Nowhere, as far as I can discover, did a single individual assert that there was such a distinct and separate thing as a Korku religion; he merely answered to the effect 'I am a Korku, but I do not know what my religion is called. I worship Mahadeo, Hunaman, Byram-Bai, Chand, Suraj, and the Bhagwant, who is the author of my religion, call it what you please'.8

The reports on the census display great frustration with classifying people into their religions; that the authorities persevered tells us more about the stubbornness of the British than the value of the classification system.

The Meos of Gurgáon and Alwar who are Musalmán to a man, and who probably hold the only considerable tract in the eastern Punjáb which is in the hands of Musalmáns only, call themselves by Hindoo names and often use Singh as an affix, worship Hindoo godlings, and very commonly belong to the Hindoo-Musalman sect of Lai Dasi, which I have described in the section under Hindooism, chiefly because I could not find a convenient place for it among Musalman sects. ${ }^{9}$

A century later, it seems obvious that there are distinct, separate religions to which people may uniquely belong. The same 'clarity' of distinctions in religions is tied into the clarity provided by a noun-based language, English. The noun-based worldview of English has caused controversies in the modern Muslim world. For example, in Classical Arabic, verb tenses are completed and incomplete, while in English there is a past, present, and future. The main element of the language is the verb, not the noun. In fact, nouns are a kind of verb. In the classical dictionary, you find that fa 'ala means he does, and secondarily that $f^{\prime} l$ is the thing that he does. Today, when someone says 'Muslim', the undergirding meaning comes from the English concept of noun - a thing. You are or you are not this particular named noun. However, in Classical Arabic, the word stays with its verbal quality. Someone who is submitting right now is a muslim. Similarly with 'Islam'. The modern English usage of the word is as a noun, but the Classical Arabic usage retains its verbal quality - the process of submission. 
- Based on a similar analysis, Mohammad Hashim Kamali says, that "[m]ainstream Qur'an commentaries consider Islam in these verses to be the exclusive name for the religion revealed to the Prophet Muhammad. But Islam is also the primal religion of submission preached by Adam to all his posterity who accepted God as their Lord, as in the divine invocation: 'Am I not your Lord? They said: Yes, we do testify' (7:172). All humankind then, before time began, professed Islam in its widest sense of submission. Understood in this way, the verses before us recognise the validity of every religion that requires submission to God's will. This understanding of Islam also tallies well with the essence of universality that Islam manifests in its own messages, values and objectives." 10

- There is no doubt that the context of the words 'Muslim' and 'Islam' needs to be appreciated.

- The idea of emptiness in Buddhism connects to the prophetic stance, telling us to question the conventional realities we think are so natural and obvious.

\section{Notes}

1. The Dalai Lama, The Universe in a Single Atom: The Convergence of Science and Spirituality (New York: Morgan Road Books, 2005).

2. Ibid., 4.

3. Ibid., 46 .

4. Ibid.

5. J.M. Schwartz, H.P. Stapp, and M. Beauregard, "Quantum Physics in Neuroscience and Psychology: A Neurophysical Model of Mind-Brain Interaction" (2005), available online at http://www.ncbi. nlm.nih.gov/pubmed/16147524 (accessed on 14 March 2011).

6. See Evelyne Andreewsky, "Formal Analogies between Classical 'Basic Units' in both Language Sciences and Other Scientific Domains" (2002), available online at http://www.afscet.asso.fr/ resSystemica/Crete02/Andreewsky.pdf (accessed on 14 March 2011).

7. See Schwartz, Stapp, and Beauregard, "Quantum Physics", 10: "How and why should that extremely limited conceptual structure, which arose basically from idealizing, by miniaturization, certain features of observed planetary motions, suffice to explain the totality of experience, with its pains, sorrows, hopes, colors, smells, and moral judgments? Why, given the known failure of classical physics at the fundamental level, should that richly endowed whole be explainable in terms of such a narrowly restricted part?"

8. W. Chichele Plowden, "Report on the Census of British India Taken on the 17th February 1881" (1883), available online at http://www.chaf.lib.latrobe.edu.au/dcd/page.php?title=\&action=next\& record=82 (accessed on 14 March 2011), 19.

9. Ibid., available online at $\mathrm{http}: / /$ www.chaf.lib.latrobe.edu.au/dcd/page.php?title=\&action=next\&r ecord=709 (accessed on 14 March 2011), 140.

10. Mohammad Hashim Kamali, "Islam's Religious Pluralism in Context", New Straits Times [Kuala Lumpur] 8 February 2011, 16. 